\title{
Maribacter dokdonensis sp. nov., isolated from sea water off a Korean island, Dokdo
}

\author{
Jung-Hoon Yoon, So-Jung Kang, Soo-Young Lee, Choong-Hwan Lee \\ and Tae-Kwang Oh
}

Correspondence

Jung-Hoon Yoon

jhyoon@kribb.re.kr

Tae-Kwang Oh

otk@kribb.re.kr

\author{
Korea Research Institute of Bioscience and Biotechnology (KRIBB), PO Box 115, Yusong, \\ Taejon, Korea
}

Two Gram-negative, non-spore-forming, slightly halophilic gliding bacterial strains, DSW-8 ${ }^{\top}$ and DSW-9, were isolated from sea water off a Korean island, Dokdo, of the East Sea, Korea, and their taxonomic position was investigated by a polyphasic study. The two strains grew optimally at $30{ }^{\circ} \mathrm{C}$ and in the presence of $2-3 \%(\mathrm{w} / \mathrm{v}) \mathrm{NaCl}$. Strains DSW-8 ${ }^{\top}$ and DSW-9 were characterized chemotaxonomically as containing MK-6 as the predominant menaquinone and iso- $\mathrm{C}_{17: 0} 3-\mathrm{OH}$, iso- $\mathrm{C}_{15: 0}$ and iso- $\mathrm{C}_{15: 1}$ as the major fatty acids. Major polar lipids were phosphatidylethanolamine, two unidentified phospholipids, an unidentified glycolipid and an amino group-containing lipid that was ninhydrin-positive. Their DNA G+C contents were $36 \cdot 1$ and $35.9 \mathrm{~mol} \%$. Phylogenetic analyses based on 16S rRNA gene sequences showed that strains DSW-8 ${ }^{\top}$ and DSW-9 fell within the genus Maribacter of the family Flavobacteriaceae. Strains DSW- $8^{\top}$ and DSW-9 exhibited no difference in their $16 \mathrm{~S}$ rRNA gene sequences and possessed a mean DNA-DNA relatedness level of $89 \%$. Strains DSW-8 ${ }^{\top}$ and DSW-9 exhibited $16 S$ rRNA gene sequence similarity levels of $96 \cdot 9-98 \cdot 0 \%$ to the type strains of the four recognized Maribacter species, but their low level of DNA-DNA relatedness with these species demonstrated that they constitute a distinct Maribacter species. On the basis of phenotypic and phylogenetic data and genetic distinctiveness, strains DSW $-8^{\top}\left(=\right.$ KCTC $12393^{\top}=\mathrm{DSM}$ $17201^{\top}$ ) and DSW-9 were classified in the genus Maribacter as members of a novel species, for which the name Maribacter dokdonensis sp. nov. is proposed.
The genus Maribacter was first described by Nedashkovskaya et al. (2004), with four species, Maribacter sedimenticola, Maribacter aquivivus, Maribacter orientalis and Maribacter ulvicola. The genus Maribacter is characterized chemotaxonomically by having MK-6 as the predominant menaquinone, iso- $\mathrm{C}_{15: 0}$, iso- $\mathrm{C}_{17: 0} 3-\mathrm{OH}$ and iso- $\mathrm{C}_{15: 1}$ as the major fatty acids and DNA G $+\mathrm{C}$ contents of $35 \cdot 0-39 \cdot 0 \mathrm{~mol} \%$ (Nedashkovskaya et al., 2004). Phylogenetic analysis based on 16S rRNA gene sequences showed that the genus falls within the family Flavobacteriaceae of the phylum CytophagaFlavobacterium-Bacteroides (Nedashkovskaya et al., 2004). In this study, we report on the detailed taxonomic characterization of two Maribacter-like bacterial strains, DSW $-8^{\mathrm{T}}$ and DSW-9, which were isolated from sea water at Dokdo, an island of the East Sea, Korea.

Sea water collected in Dokdo, Korea, provided the source for isolation of bacterial strains. Strains DSW $-8^{\mathrm{T}}$ and DSW-9 were isolated by the standard dilution plating technique on marine agar 2216 (MA; Difco) at $30{ }^{\circ} \mathrm{C}$. The type strains of

The GenBank/EMBL/DDBJ accession numbers for the 16S rRNA gene sequences of strains DSW-8 ${ }^{\top}$ and DSW-9 are AY960749 and AY960750, respectively. the four Maribacter species were used as reference strains for DNA-DNA hybridization; M. sedimenticola KCTC $12966^{\mathrm{T}}$, M. aquivivus KCTC $12968^{\mathrm{T}}$, M. orientalis KCTC $12967^{\mathrm{T}}$ and M. ulvicola KCTC $12969^{\mathrm{T}}$ were obtained from the Korean Collection for Type Cultures, Taejon, Korea. Cell morphology was examined by light microscopy (Nikon E600) and transmission electron microscopy. The presence of flagella was determined by transmission electron microscopy using cells from exponentially growing cultures. Gliding motility was investigated as described by Bowman (2000). Gram reaction was determined by using the bioMérieux Gram Stain kit according to the manufacturer's instructions. The $\mathrm{pH}$ range for growth was determined in marine broth 2216 (MB; Difco) that was adjusted to various $\mathrm{pH}$ values (initial $\mathrm{pH} 4 \cdot 5-10.5$ at intervals of $0.5 \mathrm{pH}$ units). The $\mathrm{pH}$ was adjusted prior to sterilization to various levels by the addition of $\mathrm{HCl}$ or $\mathrm{Na}_{2} \mathrm{CO}_{3}$. Growth in the absence of $\mathrm{NaCl}$ was investigated in trypticase soy broth lacking $\mathrm{NaCl}$. Growth at various $\mathrm{NaCl}$ concentrations was investigated in $\mathrm{MB}$ and trypticase soy broth (Difco). Growth at various temperatures $\left(4-40^{\circ} \mathrm{C}\right)$ was measured on MA. Growth under anaerobic conditions was determined after incubation in an anaerobic chamber on MA and on MA supplemented with nitrate, both of which had been prepared 
anaerobically using nitrogen. Catalase and oxidase activities and hydrolysis of casein and starch were determined as described by Cowan \& Steel (1965). Hydrolysis of Tweens 20, 40, 60 and 80 was determined as described by Cowan \& Steel (1965) with a modification that artificial sea water was used instead of distilled water. Hydrolysis of aesculin, gelatin and urea and nitrate reduction were determined as described by Lanyi (1987) with a modification that artificial sea water was used instead of distilled water. The artificial sea water contained (per litre of distilled water) $23.6 \mathrm{~g} \mathrm{NaCl}$, $0.64 \mathrm{~g} \mathrm{KCl}, 4.53 \mathrm{~g} \mathrm{MgCl}_{2} \cdot 6 \mathrm{H}_{2} \mathrm{O}, 5.94 \mathrm{~g} \mathrm{MgSO}_{4} .7 \mathrm{H}_{2} \mathrm{O}$ and $1.3 \mathrm{~g} \mathrm{CaCl}_{2} \cdot 2 \mathrm{H}_{2} \mathrm{O}$ (Bruns et al., 2001). Hydrolysis of hypoxanthine, tyrosine and xanthine was investigated on MA with the substrate concentrations described by Cowan \& Steel $(1965)$, i.e. $0 \cdot 4,0 \cdot 5$ and $0 \cdot 4 \%(\mathrm{w} / \mathrm{v})$, respectively. The production of $\mathrm{H}_{2} \mathrm{~S}$ was tested as described previously (Bruns et al., 2001). The presence of flexirubin pigment was investigated as described by Reichenbach (1992). Acid

Table 1. Differential phenotypic characteristics of Maribacter species

Species: 1, M. dokdonensis sp. nov.; 2, M. aquivivus; 3, M. orientalis; 4, M. sedimenticola; 5, M. ulvicola. +, Positive reaction; -, negative reaction; w, weakly positive reaction. Data in parentheses are for the type strain. All species are Gram-negative, non-flagellated, rod-shaped, non-endospore-forming and strictly aerobic. All species are positive for catalase, oxidase, gliding motility, alkaline phosphatase, NaCl requirement, growth at $4-30{ }^{\circ} \mathrm{C}$, growth in the presence of $1-5 \%(\mathrm{w} / \mathrm{v}) \mathrm{NaCl}$, hydrolysis of Tween 40 and susceptibility to lincomycin and oleandomycin. All species are negative for hydrolysis of casein and urea, production of flexirubin pigments, production of indole and $\mathrm{H}_{2} \mathrm{~S}$, Voges-Proskauer reaction, acid production from myo-inositol and D-sorbitol, utilization of citrate and susceptibility to benzylpenicillin, gentamicin, kanamycin, neomycin, polymyxin B and streptomycin.

\begin{tabular}{|c|c|c|c|c|c|}
\hline Characteristic & 1 & 2 & 3 & 4 & 5 \\
\hline Nitrate reduction & - & + & - & + & - \\
\hline$\beta$-Galactosidase activity & - & + & + & - & + \\
\hline Optimal temperature $\left({ }^{\circ} \mathrm{C}\right)$ for growth & 30 & $21-23$ & $21-23$ & $22-24$ & $21-23$ \\
\hline \multicolumn{6}{|l|}{ Growth at: } \\
\hline $6 \%(\mathrm{w} / \mathrm{v}) \mathrm{NaCl}$ & + & + & - & + & - \\
\hline $32{ }^{\circ} \mathrm{C}$ & + & - & + & + & + \\
\hline \multicolumn{6}{|l|}{ Hydrolysis of: } \\
\hline Agar & + & + & - & + & + \\
\hline Gelatin & - & + & + & - & - \\
\hline Starch & - & - & - & + & - \\
\hline Tween 20 & + & - & + & + & + \\
\hline Tween 80 & + & + & - & + & + \\
\hline \multicolumn{6}{|l|}{ Acid production from: } \\
\hline L-Arabinose & + & - & + & + & - \\
\hline D-Cellobiose & + & - & + & - & + \\
\hline D-Galactose & + & - & + & - & - \\
\hline D-Glucose & + & - & + & - & + \\
\hline Lactose & + & - & + & - & + \\
\hline Maltose & + & - & + & - & + \\
\hline Melibiose & $(\mathrm{w})$ or + & - & + & - & - \\
\hline L-Rhamnose & - & - & - & - & + \\
\hline Sucrose & + & - & + & - & + \\
\hline D-Xylose & + & - & + & - & - \\
\hline D-Raffinose & $(+)$ or $\mathrm{W}$ & - & - & - & - \\
\hline D-Mannitol & + & - & - & - & - \\
\hline \multicolumn{6}{|l|}{ Utilization of: } \\
\hline L-Arabinose & - & - & + & - & - \\
\hline D-Glucose & + & + & + & - & + \\
\hline D-Mannose & + & + & + & - & + \\
\hline Sucrose & + & + & + & - & + \\
\hline \multicolumn{6}{|l|}{ Susceptibility to antibiotics } \\
\hline Ampicillin $(10 \mu \mathrm{g}$ per disc $)$ & - & - & - & - & + \\
\hline Tetracyclin $(30 \mu \mathrm{g}$ per disc $)$ & $\mathrm{W}$ & - & - & + & - \\
\hline Carbenicillin $(100 \mu \mathrm{g}$ per disc) & - & + & + & + & + \\
\hline DNA G $+\mathrm{C}$ mol $\%$ & $35 \cdot 9-36 \cdot 1(36 \cdot 1)$ & $35 \cdot 0$ & $39 \cdot 0$ & $37 \cdot 5$ & $35 \cdot 9-36 \cdot 7(36 \cdot 7)$ \\
\hline
\end{tabular}


production from carbohydrates was determined as described by Leifson (1963). Utilization of substrates as sole carbon and energy sources was tested as described by Baumann \& Baumann (1981) using supplementation with $2 \%$ (v/v) Hutner's mineral base (Cohen-Bazire et al., 1957) and $1 \%(\mathrm{v} / \mathrm{v})$ vitamin solution (Staley, 1968). Enzyme activity was determined by using the API ZYM system (bioMérieux). Susceptibility to antibiotics was tested on MA plates using antibiotic discs containing the following concentrations: polymyxin B, $100 \mathrm{U}$; streptomycin, $50 \mu \mathrm{g}$; penicillin G, $20 \mathrm{U}$; chloramphenicol, $100 \mu \mathrm{g}$; ampicillin, $10 \mu \mathrm{g}$; cephalothin, $30 \mu \mathrm{g}$; gentamicin, $30 \mu \mathrm{g}$; novobiocin, $5 \mu \mathrm{g}$; tetracycline, $30 \mu \mathrm{g}$; kanamycin, $30 \mu \mathrm{g}$; lincomycin, $15 \mu \mathrm{g}$; oleandomycin, $15 \mu \mathrm{g}$; neomycin, $30 \mu \mathrm{g}$; carbenicillin, $100 \mu \mathrm{g}$. Other physiological and biochemical tests were performed with the API 20E system (bioMérieux).

Cell biomass of strains DSW- $8^{\mathrm{T}}$ and DSW-9 for DNA extraction and for isoprenoid quinone analysis was obtained from cultivation in $\mathrm{MB}$ at $30^{\circ} \mathrm{C}$. Cell mass of the type strains of the four Maribacter species was obtained by cultivation in $\mathrm{MB}$ at $22^{\circ} \mathrm{C}$. Chromosomal DNA was isolated and purified according to the method described previously (Yoon et al., 1996), with the exception that ribonuclease T1 was used in combination with ribonuclease A to minimize contamination with RNA. The $16 \mathrm{~S}$ rRNA gene was amplified by PCR using two universal primers as described previously (Yoon et al., 1998). Sequencing of the amplified $16 \mathrm{~S}$ rRNA gene and phylogenetic analysis were performed as described by Yoon et al. (2003). Isoprenoid quinones were extracted according to the method of Komagata \& Suzuki (1987) and analysed using reversed-phase HPLC and a YMC ODS-A $(250 \times 4.6 \mathrm{~mm})$ column. Polar lipids were extracted according to the procedures described by Minnikin et al. (1984) and identified by two-dimensional TLC followed by spraying with appropriate detection reagents (Minnikin et al., 1984; Komagata \& Suzuki, 1987). For fatty acid methyl ester analysis, cell mass of strains DSW $-8^{\mathrm{T}}$ and DSW-9 was harvested from agar plates after incubation for 3 days on MA at $30^{\circ} \mathrm{C}$. The fatty acid methyl esters were extracted and prepared according to the standard protocol of the MIDI/Hewlett Packard Microbial Identification System (Sasser, 1990). The DNA G + C content was determined by the method of Tamaoka \& Komagata (1984) with a modification that DNA was hydrolysed and the resultant nucleotides were analysed by reversed-phase HPLC. DNADNA hybridization was performed fluorometrically by the method of Ezaki et al. (1989) using photobiotin-labelled DNA probes and microdilution wells. Hybridization was performed with five replications for each sample. The highest and lowest values obtained in each sample were excluded, and the means of the remaining three values were quoted as DNA-DNA relatedness values.

Morphological, cultural, physiological and biochemical characteristics of strains DSW $-8^{\mathrm{T}}$ and DSW-9 are given in the species description (see later) and in Table 1, together with those of the four Maribacter species. Almost complete $16 \mathrm{~S}$ rRNA gene sequences of strains DSW $-8^{\mathrm{T}}$ and DSW-9, comprising 1486 nucleotides (approx. $96 \%$ of the Escherichia coli $16 \mathrm{~S}$ rRNA sequence), were determined in this study. The 16S rRNA gene sequences of strains DSW $-8^{\mathrm{T}}$ and DSW-9 were identical. Comparative 16S rRNA gene sequence analyses revealed that strains DSW $-8^{\mathrm{T}}$ and DSW-9 were most closely affiliated to members of the genus Maribacter of the family Flavobacteriaceae. In the neighbourjoining tree based on 16S rRNA gene sequences, strains DSW $-8^{\mathrm{T}}$ and DSW-9 fell within the radiation of the cluster comprising the four recognized Maribacter species, joining M. sedimenticola at a bootstrap confidence level of $90 \cdot 1 \%$ (Fig. 1). Similar tree topologies were found in the trees generated with the maximum-likelihood and maximumparsimony algorithms (data not shown). The 16S rRNA gene sequences of strains DSW $-8^{\mathrm{T}}$ and DSW-9 exhibited similarity values of $96 \cdot 9-98 \cdot 0 \%$ to those of the type strains of the Maribacter species. The two strains exhibited $16 \mathrm{~S}$

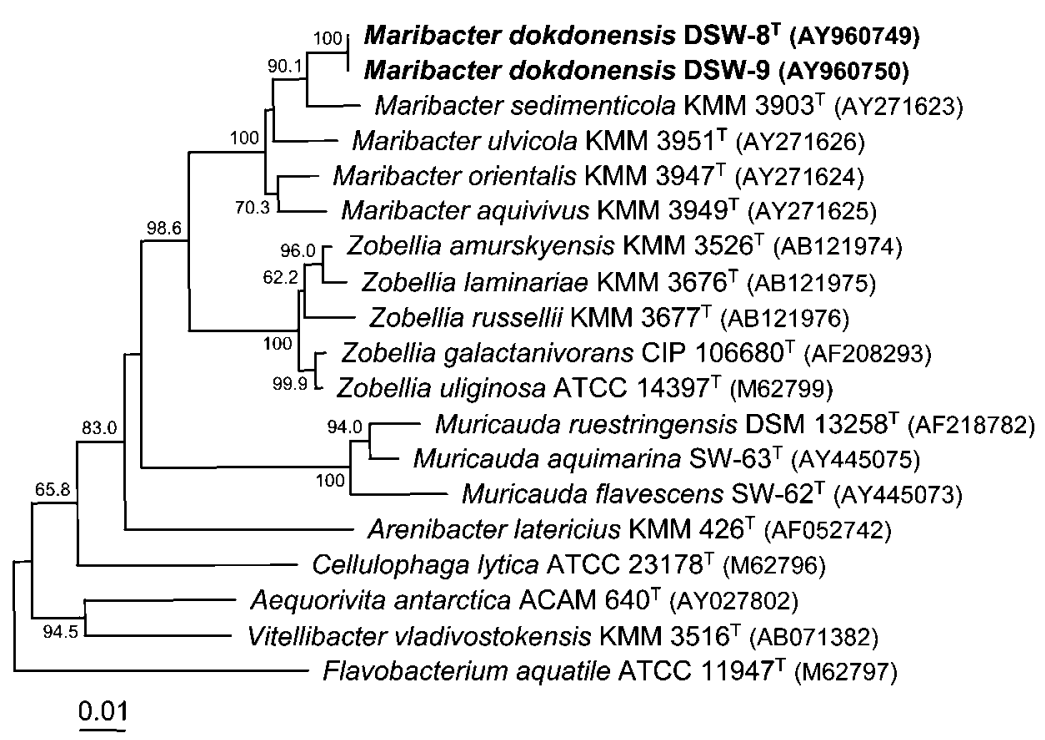

Fig. 1. Neighbour-joining tree based on 16S rRNA gene sequences showing the phylogenetic positions of strains DSW-8 ${ }^{\top}$ and DSW-9, the Maribacter species and representatives of some other related taxa. Bootstrap values (expressed as percentages of 1000 replicates) greater than $50 \%$ are shown at the branching points. Flavobacterium aquatile ATCC $11947^{\top}$ was used as an outgroup. Scale bar, 0.01 substitutions per nucleotide position. 
rRNA gene sequence similarity values of $93 \cdot 4-94 \cdot 2 \%$ to Zobellia species, $90 \cdot 1-91 \cdot 4 \%$ to Muricauda species and less than $90.9 \%$ to other species used in the phylogenetic analysis (Fig. 1).

The predominant isoprenoid quinone found in strains DSW $-8^{\mathrm{T}}$ and DSW-9 was menaquinone-6 (MK-6) at a peak area ratio of approximately $93-95 \%$. Strains DSW $-8^{\mathrm{T}}$ and DSW-9 had cellular fatty acid profiles that contained large amounts of straight-chain, branched and hydroxyl fatty acids; the major fatty acids were iso- $\mathrm{C}_{17: 0} 3-\mathrm{OH}$, iso- $\mathrm{C}_{15: 0}$ and iso- $\mathrm{C}_{15: 1}$ (Table 2). These fatty acid profiles were similar to those of the Maribacter species, although there were differences in the proportions of some fatty acids that might have been caused by different cultivation conditions (Table 2). Phosphatidylethanolamine was the only phospholipid identified in strains DSW $-8^{\mathrm{T}}$ and DSW-9, and other major polar lipids were two unidentified phospholipids, an unidentified glycolipid and an amino groupcontaining lipid that was ninhydrin-positive. These chemotaxonomic properties support the attribution of strains DSW $-8^{\mathrm{T}}$ and DSW-9 to the genus Maribacter (Nedashkovskaya et al., 2004).

The DNA G + C contents of strains DSW $-8^{\mathrm{T}}$ and DSW-9 were $36 \cdot 1$ and $35 \cdot 9 \mathrm{~mol} \%$. The mean level of DNA-DNA relatedness between strains DSW $-8^{\mathrm{T}}$ and DSW-9 was $89 \%$, when their DNAs were used individually as labelled DNA probes for cross-hybridization, indicating that the two strains are members of the same genomic species, as suggested by the results of the phenotypic and phylogenetic analyses. The two strains differed from the other Maribacter species by several phenotypic characteristics (Table 1), and the level of their DNA-DNA relatedness with the type strains of these species was 11-21\% (Wayne et al., 1987). Therefore, on the basis of the data presented, strains DSW $-8^{\mathrm{T}}$ and DSW-9 should be placed in the genus Maribacter as members of a novel species, for which the name Maribacter dokdonensis sp. nov. is proposed.

\section{Description of Maribacter dokdonensis sp. nov.}

Maribacter dokdonensis (dok.do.nen'sis. N.L. masc. adj. dokdonensis pertaining to Dokdo, the Korean island from where the strains were isolated).

Cells are rods, $0 \cdot 3-0 \cdot 4 \times 0 \cdot 8-4 \cdot 0 \mu \mathrm{m}$. Colonies are circular or rhizoid, glistening, slightly convex, yellow in colour and $1 \cdot 0-2 \cdot 0 \mathrm{~mm}$ in diameter after incubation for 3 days on MA at $30^{\circ} \mathrm{C}$. Optimal growth temperature is $30^{\circ} \mathrm{C}$; growth occurs at 4 and $35^{\circ} \mathrm{C}$, but not at $36^{\circ} \mathrm{C}$. Optimal pH for growth is $7 \cdot 0-8 \cdot 0$; growth occurs at $\mathrm{pH} 5 \cdot 5$, but not at $5 \cdot 0$. Optimal growth occurs in the presence of $2-3 \%(\mathrm{w} / \mathrm{v})$ $\mathrm{NaCl}$; growth does not occur in the absence of $\mathrm{NaCl}$ and in the presence of greater than $10 \%(\mathrm{w} / \mathrm{v}) \mathrm{NaCl}$. Aesculin, tyrosine and Tween 60 are hydrolysed, but hypoxanthine and xanthine are not. Anaerobic growth does not occur on MA and on MA supplemented with nitrate. Arginine dihydrolase, lysine decarboxylase, ornithine decarboxylase
Table 2. Cellular fatty acid composition (\%) of Maribacter species

Strains: 1, M. dokdonensis DSW-8 ${ }^{\mathrm{T}}$; 2, M. dokdonensis DSW-9; 3, M. aquivivus $\mathrm{KMM} 3949^{\mathrm{T}}$; 4, M. orientalis $\mathrm{KMM} 3947^{\mathrm{T}}$; 5, M. sedimenticola KMM $3903^{\mathrm{T}}$; 6, M. ulvicola $\mathrm{KMM} 3951^{\mathrm{T}}$. -, Not detected. Fatty acids that represented $<0.5 \%$ in all strains were omitted.

\begin{tabular}{|c|c|c|c|c|c|c|}
\hline Fatty acid & 1 & 2 & 3 & 4 & 5 & 6 \\
\hline \multicolumn{7}{|l|}{ Straight-chain fatty acid } \\
\hline $\mathrm{C}_{14: 0}$ & $0 \cdot 9$ & $0 \cdot 9$ & $1 \cdot 0$ & $0 \cdot 5$ & $0 \cdot 5$ & $0 \cdot 9$ \\
\hline $\mathrm{C}_{15: 0}$ & $3 \cdot 8$ & $3 \cdot 5$ & $14 \cdot 5$ & $12 \cdot 3$ & $6 \cdot 3$ & $8 \cdot 1$ \\
\hline $\mathrm{C}_{16: 0}$ & $1 \cdot 4$ & $1 \cdot 3$ & $0 \cdot 5$ & $1 \cdot 2$ & $1 \cdot 0$ & $1 \cdot 0$ \\
\hline \multicolumn{7}{|l|}{ Branched fatty acid } \\
\hline iso- $\mathrm{C}_{13: 0}$ & $0 \cdot 6$ & $0 \cdot 6$ & - & - & - & - \\
\hline iso- $\mathrm{C}_{15: 0}$ & $19 \cdot 7$ & $20 \cdot 3$ & $12 \cdot 3$ & $10 \cdot 6$ & $20 \cdot 5$ & $13 \cdot 6$ \\
\hline iso- $\mathrm{C}_{15: 1}$ & $16 \cdot 1$ & $15 \cdot 7$ & $13 \cdot 6$ & $10 \cdot 1$ & $16 \cdot 9$ & $18 \cdot 9$ \\
\hline anteiso- $\mathrm{C}_{15: 0}$ & $0 \cdot 3$ & $0 \cdot 4$ & $1 \cdot 3$ & $2 \cdot 3$ & $1 \cdot 2$ & $1 \cdot 9$ \\
\hline iso- $\mathrm{C}_{16: 0}$ & - & - & $0 \cdot 7$ & $0 \cdot 3$ & $1 \cdot 1$ & $0 \cdot 3$ \\
\hline iso- $\mathrm{C}_{17: 1} \omega 5 c$ & - & - & $1 \cdot 4$ & - & - & $1 \cdot 2$ \\
\hline iso- $\mathrm{C}_{17: 1} \omega 9 c$ & $2 \cdot 0$ & $2 \cdot 2$ & $2 \cdot 2$ & $4 \cdot 0$ & $2 \cdot 3$ & $2 \cdot 2$ \\
\hline iso- $\mathrm{C}_{18: 1}$ & - & - & - & $2 \cdot 4$ & - & - \\
\hline \multicolumn{7}{|l|}{ Unsaturated fatty acid } \\
\hline $\mathrm{C}_{13: 1}$ & - & - & $1 \cdot 1$ & $0 \cdot 3$ & $0 \cdot 7$ & $1 \cdot 1$ \\
\hline $\mathrm{C}_{14: 1} \omega 5$ & - & - & $1 \cdot 0$ & - & - & $0 \cdot 9$ \\
\hline $\mathrm{C}_{15: 1} \omega 6 c$ & $0 \cdot 6$ & $0 \cdot 6$ & $4 \cdot 8$ & $2 \cdot 5$ & $1 \cdot 7$ & $1 \cdot 6$ \\
\hline $\mathrm{C}_{17: 1} \omega 6 c$ & $0 \cdot 2$ & $0 \cdot 2$ & $1 \cdot 7$ & $1 \cdot 3$ & $0 \cdot 5$ & $0 \cdot 5$ \\
\hline \multicolumn{7}{|l|}{ Hydroxy fatty acid } \\
\hline $\mathrm{C}_{15: 0} 3-\mathrm{OH}$ & $1 \cdot 4$ & $1 \cdot 4$ & $2 \cdot 3$ & $1 \cdot 5$ & $2 \cdot 4$ & $1 \cdot 5$ \\
\hline iso- $\mathrm{C}_{15: 0} 3-\mathrm{OH}$ & $5 \cdot 0$ & $5 \cdot 0$ & $3 \cdot 2$ & $2 \cdot 9$ & $5 \cdot 4$ & $4 \cdot 1$ \\
\hline $\mathrm{C}_{16: 0} 3-\mathrm{OH}$ & $5 \cdot 4$ & $5 \cdot 5$ & $2 \cdot 9$ & $3 \cdot 0$ & $2 \cdot 2$ & $3 \cdot 7$ \\
\hline iso- $\mathrm{C}_{16: 0} 3-\mathrm{OH}$ & $1 \cdot 1$ & $1 \cdot 0$ & $2 \cdot 5$ & $2 \cdot 1$ & $1 \cdot 7$ & $1 \cdot 7$ \\
\hline iso- $\mathrm{C}_{17: 0} 3-\mathrm{OH}$ & $28 \cdot 6$ & $29 \cdot 2$ & $11 \cdot 6$ & $18 \cdot 8$ & $20 \cdot 4$ & $14 \cdot 5$ \\
\hline \multicolumn{7}{|l|}{ Summed feature ${ }^{\star}$} \\
\hline 3 & $8 \cdot 6$ & $8 \cdot 4$ & $12 \cdot 9$ & $11 \cdot 4$ & $5 \cdot 8$ & $12 \cdot 2$ \\
\hline Unknown fatty acid(s) & $2 \cdot 7 \dagger$ & $3 \cdot 0 \dagger$ & $10 \cdot 2$ & $5 \cdot 9$ & $7 \cdot 9$ & $10 \cdot 3$ \\
\hline
\end{tabular}

*Summed feature represent groups of two or three fatty acids which could not be separated by GLC with the MIDI system. Summed feature 3 contained $\mathrm{C}_{16: 1} \omega 7 c$ and/or iso- $\mathrm{C}_{15: 0} 2-\mathrm{OH}$.

$\dagger$ Sum of ECL (equivalent chain-length) $13 \cdot 565$ and $16 \cdot 582$.

and tryptophan deaminase are absent. In assays with the API ZYM system, esterase (C4), esterase lipase (C8), leucine arylamidase, acid phosphatase, naphthol-AS-BIphosphohydrolase, $\beta$-glucosidase and $N$-acetyl- $\beta$-glucosaminidase are present, but lipase (C14), valine arylamidase, cystine arylamidase, trypsin, $\alpha$-chymotrypsin, $\alpha$-galactosidase, $\beta$-galactosidase, $\beta$-glucuronidase, $\alpha$-glucosidase, $\alpha$-mannosidase and $\alpha$-fucosidase are absent. D-Fructose, D-galactose, D-cellobiose, D-trehalose, D-xylose, maltose and salicin are utilized, but acetate, succinate, benzoate, L-malate, pyruvate, formate and L-glutamate are not utilized. Acid is produced from D-mannose, D-melezitose and D-trehalose, but acid is not produced from D-ribose. Acid production from Dfructose is variable (positive for the type strain). Susceptible 
to novobiocin $(5 \mu \mathrm{g})$, but not to cephalothin $(30 \mu \mathrm{g})$. The predominant menaquinone is MK-6. The major fatty acids are iso- $\mathrm{C}_{17: 0} 3-\mathrm{OH}$, iso- $\mathrm{C}_{15: 0}$ and iso- $\mathrm{C}_{15: 1}$. The major polar lipids are phosphatidylethanolamine, two unidentified phospholipids, an unidentified glycolipid and an amino group-containing lipid that is ninhydrin-positive. The DNA $\mathrm{G}+\mathrm{C}$ content is $35 \cdot 9-36 \cdot 1 \mathrm{~mol} \%$ (HPLC) $(36 \cdot 1 \mathrm{~mol} \%$ for type strain). Other characteristics are shown in Table 1.

The type strain, DSW $-8^{\mathrm{T}}\left(=\right.$ KCTC $\left.12393^{\mathrm{T}}=\mathrm{DSM} 17201^{\mathrm{T}}\right)$, was isolated from sea water off Dokdo, an island located at the edge of the East Sea, Korea. Another reference strain is DSW-9.

\section{Acknowledgements}

This work was supported by the 21C Frontier program of Microbial Genomics and Applications (grant MG02-0401-001-1-0-0) from the Ministry of Science and Technology (MOST) of the Republic of Korea. We are grateful to the Cultural Heritage Administration and to the Gyeongsangbuk-do Administration of the Republic of Korea for facilitating the access to Dokdo.

\section{References}

Baumann, P. \& Baumann, L. (1981). The marine Gram-negative eubacteria: genera Photobacterium, Beneckea, Alteromonas, Pseudomonas, and Alcaligenes. In The Prokaryotes, pp. 1302-1331. Edited by M. P. Starr, H. Stolp, H. G. Trüper, A. Balows \& H. G. Schlegel. Berlin: Springer.

Bowman, J. P. (2000). Description of Cellulophaga algicola sp. nov., isolated from the surfaces of Antarctic algae, and reclassification of Cytophaga uliginosa (ZoBell and Upham 1944) Reichenbach 1989 as Cellulophaga uliginosa comb. nov. Int J Syst Evol Microbiol 50, 1861-1868.

Bruns, A., Rohde, M. \& Berthe-Corti, L. (2001). Muricauda ruestringensis gen. nov., sp. nov., a facultatively anaerobic, appendaged bacterium from German North Sea intertidal sediment. Int J Syst Evol Microbiol 51, 1997-2006.

Cohen-Bazire, G., Sistrom, W. R. \& Stanier, R. Y. (1957). Kinetic studies of pigment synthesis by nonsulfur purple bacteria. J Cell Comp Physiol 49, 25-68.

Cowan, S. T. \& Steel, K. J. (1965). Manual for the Identification of Medical Bacteria. London: Cambridge University Press.

Ezaki, T., Hashimoto, Y. \& Yabuuchi, E. (1989). Fluorometric deoxyribonucleic acid- deoxyribonucleic acid hybridization in microdilution wells as an alternative to membrane filter hybridization in which radioisotopes are used to determine genetic relatedness among bacterial strains. Int J Syst Bacteriol 39, 224-229.

Komagata, K. \& Suzuki, K. (1987). Lipids and cell-wall analysis in bacterial systematics. Methods Microbiol 19, 161-203.

Lanyi, B. (1987). Classical and rapid identification methods for medically important bacteria. Methods Microbiol 19, 1-67.

Leifson, E. (1963). Determination of carbohydrate metabolism of marine bacteria. J Bacteriol 85, 1183-1184.

Minnikin, D. E., O’Donnell, A. G., Goodfellow, M., Alderson, G., Athalye, M., Schaal, A. \& Parlett, J. H. (1984). An integrated procedure for the extraction of bacterial isoprenoid quinones and polar lipids. J Microbiol Methods 2, 233-241.

Nedashkovskaya, O. I., Kim, S. B., Han, S. K. \& 7 other authors (2004). Maribacter gen. nov., a new member of the family Flavobacteriaceae, isolated from marine habitats, containing the species Maribacter sedimenticola sp. nov., Maribacter aquivivus sp. nov., Maribacter orientalis sp. nov. and Maribacter ulvicola sp. nov. Int J Syst Evol Microbiol 54, 1017-1023.

Reichenbach, H. (1992). The order Cytophagales. In the Prokaryotes. A Handbook on the Biology of Bacteria: Ecophysiology, Isolation, Identification, Applications, 2nd edn, pp. 3631-3675. Edited by A. Balows, H. G. Trüper, M. Dworkin, W. Harder \& K. H. Schleifer. New York: Springer.

Sasser, M. (1990). Identification of Bacteria by Gas Chromatography of Cellular Fatty Acids. Newark, DE: MIDI.

Staley, J. T. (1968). Prosthecomicrobium and Ancalomicrobium: new prosthecate freshwater bacteria. J Bacteriol 95, 1921-1942.

Tamaoka, J. \& Komagata, K. (1984). Determination of DNA base composition by reverse-phase high-performance liquid chromatography. FEMS Microbiol Lett 25, 125-128.

Wayne, L. G., Brenner, D. J., Colwell, R. R. \& 9 other authors (1987). International Committee on Systematic Bacteriology. Report of the ad hoc committee on reconciliation of approaches to bacterial systematics. Int J Syst Bacteriol 37, 463-464.

Yoon, J.-H., Kim, H., Kim, S.-B., Kim, H.-J., Kim, W. Y., Lee, S. T., Goodfellow, M. \& Park, Y.-H. (1996). Identification of Saccharomonospora strains by the use of genomic DNA fragments and rRNA gene probes. Int J Syst Bacteriol 46, 502-505.

Yoon, J.-H., Lee, S. T. \& Park, Y.-H. (1998). Inter- and intraspecific phylogenetic analysis of the genus Nocardioides and related taxa based on 16S rRNA gene sequences. Int J Syst Bacteriol 48, 187-194.

Yoon, J.-H., Kang, K. H. \& Park, Y.-H. (2003). Psychrobacter jeotgali sp. nov., isolated from jeotgal, a traditional Korean fermented seafood. Int J Syst Evol Microbiol 53, 449-454. 